\title{
大東花崗閃緑岩の赤色風化
}

——深成岩類の風化に関する研究 (第 3 報)——.

三 浦 清*

\section{The Weathering of Daito Granodiorite Mass, Shimane Prefecture, Japan}

-Weathering in Plutonic Rocks (Part 3) _

Kiyoshi MiUra

The Daito granodiorite mass is widely exposed in Kisuki-Daito district. This rock has a somewhat homogeneous composition and is medium to coarse-grained rock consisting chiefly of plagioclase, quartz, orthoclase, biotite and hornbelnde, accompanied by small quantites of apatite, magnetite, zircon and sphane.

Whole rock and their biotite were examined by X-ray powder diffraction method and chemical analysis.

The grade of chemical weathering that have taken place in rocks was determined by A.D.F. proposed by present writer.

The amount of leaching from the parent rocks, relating to the cation, have intimate relations with A.D.F.

By weathering reaction, biotite is altered to the mixed matters composed of biotite and kaolinite at about 15 in A.D.F., passing through the mixed matters composed of unstable biotite, interstratified biotite-vermiculite mineral and kaolinite at about 89 , interstratified vermiculite-montmorillonite mineral, interstratified biotitevermiculite mineral and kaolinite at about 77 , interstratified biotite-(vermiculitechlorite intergrade) mineral and kaolinite at about 19 in A.D.F. value.

The results indicates that the altered products of biotite gives a measure of the proceeding on the weathering process of parental rock.

\section{1. まえがき}

侵食, 崩壊などのいわゆる地盤変動に関する調査, 研 究などにおいて，岩石の風化が占める役割が大きいこと は当然である。しかしながら，これら応用地質学的分野 と岩石学的分野との間が充分に埋められているとは云え ない。筆者はこの領域を指向しつつ, 研究を進めている が，本論文もとの一貫として書かれたものである。

\section{2. 地質 概 説}

大東花崗閃緑岩体は，木次附近を中心として NE-SW 方向に帯状をなして延長する岩体で河野等 ${ }^{1)}$ の研究によ るとその貫入時期は 44 58 (my) と考えられている。本 岩体をはさんでその南北には，これに貫入する黒雲母花 崗岩が分布する (図-1 参照)。これらを被覆して, 第四 紀の大山, 三瓶両火山起源の火山降下堆積物を見ること がある。

本岩体の風化帯には, 豪雨性崩壊が多発し, それに関

\footnotetext{
$*$ 島根大学教育学部地学研究室
}

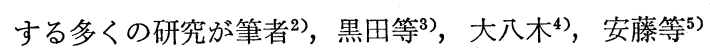
などによってなされ，報告されている。

\section{3. 大東花崗閃緑岩体の岩石学的性質}

本岩石は，やや粗粒で，一般に塩基性包有岩片を含む ことが多い。

主成分鉱物は石英, 斜長石, 正長石, 黒雲母, 角閃石 からなり, 少量の磁鉄鉱, 燐灰石, クサビ石, ジルコン などを含を。

石英は不規則な外形を示し，大きいもので $2 \mathrm{~mm} \times 2$ $\mathrm{mm}$ 程度である。

カリ長石はすべて正長石で，大きいものでは $2.5 \mathrm{~mm}$ のものが観察される。一般に短柱状をなし，わずかにパ 一サイト構造を示し, 斜長石との接触部で微文象構造が 認められることがある。

斜長石は，他の造岩鉱物に比して，やや明瞭な結晶輪 郭を示し，カルルスバッド，アルバイト，ペリクリン式 などの双晶を示す。大きいもので $4.5 \times 2.2 \mathrm{~mm}$ 程度の 大いさをもつ。平均的に斜長石の An 含量は 29 〜 $30 \%$ 

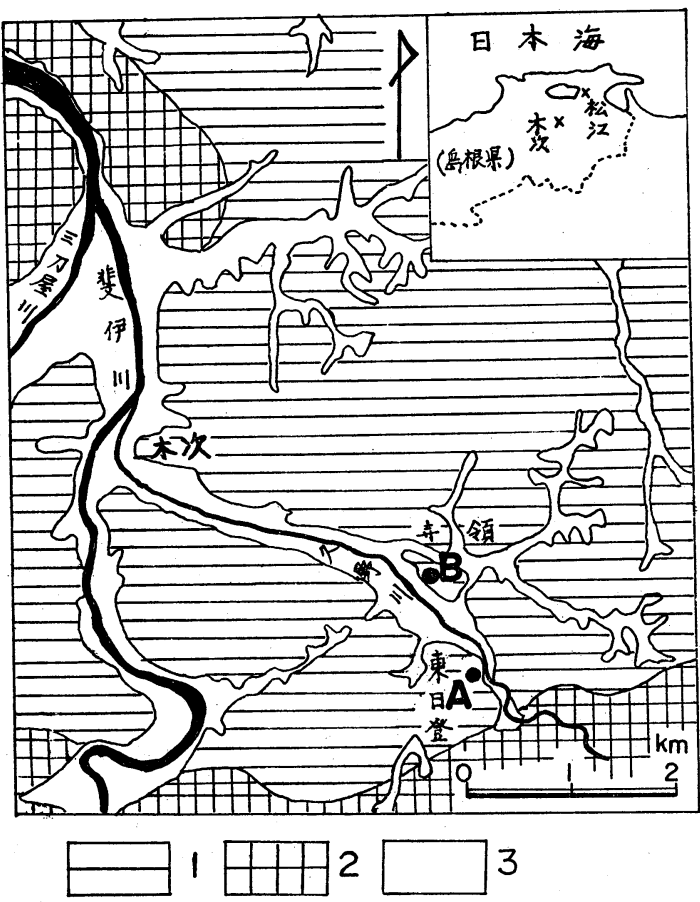

1: 大東花崗閃緑岩, 2: 黒雲母花崗岩, 3 : 沖積層 A点：試料 48031501, 49051001, 49051002 採取地点 B点：試料 $48031502,48031503,48031504,48031505$ 採取地点

図-1 地 質 図
表-1·造岩鉱物の容量パーセント

\begin{tabular}{|c|c|c|c|}
\hline 造 & 岩 & 物 & 容量パーセント \\
\hline 石 & & 英 & 26.36 \\
\hline 斜 & 長 & 石 & 51.12 \\
\hline 正 & 長 & 石 & 13.35 \\
\hline 黒 & 雲 & 母 & 6.20 \\
\hline 角 & 閃 & 石 & 2.50 \\
\hline r & の & 他 & 0.47 \\
\hline \multicolumn{3}{|c|}{ 計 } & 100.00 \\
\hline \multicolumn{3}{|c|}{ 斜長石の An (\%) } & $30 \sim 28$ \\
\hline
\end{tabular}

程度である。

黒雲母は $1.6 \times 1.4 \mathrm{~mm}$ 程度の大きさを示し, 時には緑 泥石，緑策石化を受けていることがある。

角閃石は長柱状を示し，その大きさは大きいもので $4 \mathrm{~mm} \times 1.5 \mathrm{~mm}$ 程度である。

造岩鉱物の含量は，産地によって多少の変化が認めら れるが，平均的には 表-1 に示すようなものである。 Chayes $^{6)}$ の分類に従うなら B/H II $\mathrm{P}_{9.17}$ とすべきであろ う。なお，表-2 の（1）は，図-1 のA地点で採取した 3 個の新鮮な岩石の化学組成の平均值を示したものであ る。

表-2 新体岩とその風化岩ならびに崖錐土の化学組成

\begin{tabular}{|c|c|c|c|c|c|c|c|}
\hline 成 分 番 号 & (1) & (2) & (3) & (4) & ( 5 ) & (6) & (7) \\
\hline $\mathrm{SiO}_{2}$ & 66.30 & 65.24 & 65.29 & 62.70 & 59.60 & 58.58 & 54.87 \\
\hline $\mathrm{TiO}_{2}$ & 0.55 & 0.65 & 0.67 & 0.70 & 1.00 & 0.77 & 0.78 \\
\hline $\mathrm{Al}_{2} \mathrm{O}_{3}$ & 15.24 & 16.28 & 17.58 & 19.08 & 19.53 & 18.45 & 24.09 \\
\hline $\mathrm{Fe}_{2} \mathrm{O}_{3}$ & 1.76 & 2.50 & 1.05 & 5.07 & 6.55 & 8.19 & 4.50 \\
\hline $\mathrm{FeO}$ & 2.42 & 2.00 & 1.11 & 0.33 & 0.25 & 0.32 & 0.28 \\
\hline $\mathrm{MnO}$ & 0.07 & 0.08 & 0.08 & 0.02 & 0.02 & 0.01 & 0.01 \\
\hline $\mathrm{MgO}$ & 2.11 & 2.35 & 1.97 & 0.64 & 0.41 & 0.87 & 0.80 \\
\hline $\mathrm{CaO}$ & 3.91 & 4.25 & 3.69 & 0.41 & 0.05 & 0.02 & 0.01 \\
\hline $\mathrm{Na}_{2} \mathrm{O}$ & 3.64 & 3.76 & 3.86 & 0.56 & 0.31 & 0.26 & 0.16 \\
\hline $\mathrm{K}_{2} \mathrm{O}$ & 248 & 1.81 & 1.75 & 2.57 & 2.49 & 2.52 & 1.94 \\
\hline $\mathrm{H}_{2} \mathrm{O}(-)$ & 0.24 & 0.24 & 0.67 & 1.66 & 2.31 & 2.52 & 3.77 \\
\hline $\mathrm{H}_{2} \mathrm{O}(+)$ & 1.06 & 1.03 & 1.50 & 6.25 & 7.77 & 8.09 & 8.81 \\
\hline $\mathrm{P}_{2} \mathrm{O}_{5}$ & 0.15 & 0.22 & 0.10 & 0.10 & 0.10 & 0.36 & 0.12 \\
\hline Total & 99.93 & 100.41 & 99.32 & 100.09 & 100.39 & 100.96 & 100.14 \\
\hline A.D.F. & 100.00 & 88.89 & 76.54 & 18.52 & 12.35 & 14.81 & 11.11 \\
\hline
\end{tabular}
$\begin{array}{ll}\text { (1) }: 48031501 & \text { (2): } 49051001\end{array}$
(3) : 49051002
(4) : 48031502
(5) : 48031503
(6) : 48031504

(7)：48031505（崖錐土） 
表 -3 研究試料の地質的諸元

\begin{tabular}{|c|c|c|c|c|c|c|c|}
\hline 試料番号 & 採 取 地 点 & 地 & 質 & 係 & 風化土色調 & 密 & A.D.F. \\
\hline 48031501 & 図-1 A 地点 & 新鮮 & 花崗閃緑 & & & 2.75 & 100.00 \\
\hline 49051001 & " & 新鮮 & & 約 $4 \mathrm{~m}$ & & & 88.89 \\
\hline 49051002 & " & & & $13 \mathrm{~m}$ & & & 76.54 \\
\hline 48031502 & 図-2 $\mathrm{B}$ 地点 & 崖錐 & 基底部下 & $3.7 \mathrm{~m}$ & $7.5 \mathrm{Y} \mathrm{R} 8 / 6$ & & 18.52 \\
\hline 48031503 & " & & " & $2.5 \mathrm{~m}$ & $10 \mathrm{R} 7 / 8$ & 1.27 & 12.35 \\
\hline 48031504 & " & & " & $1.3 \mathrm{~m}$ & $10 \mathrm{R} 6 / 8$ & 1.24 & 14.81 \\
\hline 48031505 & " & 崖錐 & 基底部分 & （崖錐土） & $10 \mathrm{R} 5 / 8$ & 1.29 & 11.11 \\
\hline
\end{tabular}

\section{4. 風化作用の時代}

上述のように，本岩体は，場所によって，第四紀火山 の降下堆積物によって被覆され，それを利用して風化を 受けた時代を推定することが出来る。

赤色風化の模式地は，図-1 の B 地点, すなわち，木 次町寺領小学校運動場の崖地である。ここでは, 最上部 に，二枚の火山降下堆積物がみられ，その直下に約 $1 \mathrm{~m}$ の花崗閃緑岩起源の古崖錐堆積物をみることが出来，そ の下位から，いわゆる花崗閃緑岩となっている。二枚の 火山降下堆積物のうち，上位のものは松井等7によると 三瓶火山起源のもので，その時代は少なくとも25,600 $\pm 1,000$ 年よりもやや古いとされている。一方, 下位の ものは，大山中部火山灰に相当し，その降下年代は， $30,200 \pm 3,500$ 年と考えられている8)。

この露頭で見る限り，下部の火山降下堆積物には赤色 風化作用の影響がみられるが，上部の火山降下堆積物に はみられない。

赤色風化作用の開始時期については不明であるが，そ の末期は少なくともこの上下両火山降下堆積物の時代差 の間に入ってるくことだけは明らかである。

\section{5. 研 究 試 料}

実際問題として，一露頭で新鮮なものから赤色土化し たものまで観察される場合は稀れであろう。この地域に おいても，そのような露頭は存在しないので，図-1 の A， B地点にまたがって研究試料を採取した。その地質 的関係などを 表-3 に示す。

前述のように, B地点では風化試料上に直接約 $1 \mathrm{~m}$ の 厚さをもつ古崖錐土が堆積し，さらにその上を上下二枚 の火山降下堆積物が被覆する。そして下部火山降下堆積 物以下が赤色風化を受けて赤色土化し，下部に向って次 第に黄色化する。

全体としてみるなら，上部から下部に向って A.D.F. 值9)増している。

\section{6. 風化作用による岩石の化学組成変化}

表-2 は新鮮岩とその風化岩ならびに崖錐土の化学組 成を A.D.F.の值と共に示したものである。分析值に示 されるごとく，相対的変化量として $\mathrm{Fe}_{2} \mathrm{O}_{3}, \mathrm{Al}_{2} \mathrm{O}_{3}, \mathrm{H}_{2} \mathrm{O}$ などは風化の進行につれて増加し，逆に $\mathrm{FeO}, \mathrm{MnO}$, $\mathrm{MgO}, \mathrm{CaO}, \mathrm{Na}_{2} \mathrm{O}$ は特徵的に減少する。 $\mathrm{K}_{2} \mathrm{O}$ の变化は 少ない。

これら分析值に示される值の変化は相対的なものであ るから，密度測定試料について岩石中 $1 \mathrm{~m}^{3}$ の各酸化物 のグラム数，モル数，グラムイオン数を求めることによ って，それらの絶対的な变化量を得た。その結果を表一 $4,5,6$ に示す。

表-7 は 表-6 の值から計算した各陽イオンについて, 岩石の風化にともなう減少率ならびに増加率を示したも のである。

これによると A.D.F.=12.35 のものでは各イオンの 表 $-4 \quad 1 \mathrm{~m}^{3}$ 中のグラム数

\begin{tabular}{l|r|r|r|r}
\hline \multicolumn{1}{r|}{ 番号 } & \multicolumn{1}{c|}{$(1)$} & \multicolumn{1}{c|}{$(2)$} & \multicolumn{1}{c}{$(3)$} & \multicolumn{1}{c}{$(4)$} \\
成分 & & & & \\
\hline $\mathrm{SiO}_{2}$ & $1,824,900$ & 753,974 & 719,485 & 706,830 \\
$\mathrm{TiO}_{2}$ & 15,125 & 12,649 & 9,461 & 10,049 \\
$\mathrm{Al}_{2} \mathrm{O}_{3}$ & 419,375 & 247,066 & 226,610 & 310,322 \\
$\mathrm{Fe}_{2} \mathrm{O}_{3}$ & 48,400 & 82,855 & 100,589 & 57,973 \\
$\mathrm{FeO}$ & 66,550 & 3,162 & 3,931 & 3,612 \\
$\mathrm{MnO}$ & 1,925 & 254 & 124 & 129 \\
$\mathrm{MgO}$ & 58,025 & 5,182 & 10,689 & 10,307 \\
$\mathrm{CaO}$ & 107,525 & 635 & 248 & 129 \\
$\mathrm{Na}{ }_{2} \mathrm{O}$ & 100,100 & 3,924 & 3,199 & 2,064 \\
$\mathrm{~K}_{2} \mathrm{O}$ & 68,200 & 31,496 & 30,950 & 24,987 \\
$\mathrm{H}_{2} \mathrm{O}(-)$ & 6,600 & 29,223 & 30,950 & 48,569 \\
$\mathrm{H}_{2} \mathrm{O}(+)$ & 29,150 & 98,298 & 99,361 & 113,494 \\
$\mathrm{P}_{2} \mathrm{O}_{5}$ & 4,125 & 1,270 & 4,427 & 1,548 \\
\hline
\end{tabular}

$\begin{array}{llll}(1): 48031501 & \text { (2): } 48031503 \quad \text { (3): } 48031504\end{array}$ (4)：48031505（崖錐土） 
表-5 $1 \mathrm{~m}^{3}$ 中のモル数

\begin{tabular}{|c|c|c|c|c|}
\hline 成分 番号 & (1) & (2) & (3) & (4) \\
\hline $\mathrm{SiO}_{2}$ & 80,385 & 12,554 & 11,979 & 11,769 \\
\hline $\mathrm{TiO}_{2}$ & 189 & 158 & 118 & 126 \\
\hline $\mathrm{Al}_{2} \mathrm{O}_{3}$ & 4,114 & 2,424 & 2,223 & 3,044 \\
\hline $\mathrm{Fe}_{2} \mathrm{O}_{3}$ & 303 & 519 & 630 & 363 \\
\hline$\dot{\mathrm{FeO}}$ & 926 & 44 & 55 & 50 \\
\hline $\mathrm{MnO}$ & 27 & 4 & 2 & 2 \\
\hline $\mathrm{MgO}$ & 1,439 & 129 & 265 & 256 \\
\hline $\mathrm{CaO}$ & 1,917 & 11 & 4 & 2 \\
\hline $\mathrm{Na}_{2} \mathrm{O}$ & 1,616 & 63 & 52 & 33 \\
\hline $\mathrm{K}_{2} \mathrm{O}$ & 724 & 334 & 329 & 265 \\
\hline $\mathrm{H}_{2} \mathrm{O}(-)$ & 367 & 1,624 & 1,719 & 2,698 \\
\hline $\mathrm{H}_{2} \mathrm{O}(+)$ & 1,619 & 5,461 & 5,520 & 6,305 \\
\hline $\mathrm{P}_{2} \mathrm{O}_{5}$ & 29 & 9 & 31 & 11 \\
\hline
\end{tabular}

$\begin{array}{lll}\text { (1) : } 48035101 & \text { (2): } 48031503 & \text { (3) : } 48031504\end{array}$ (4)：48031505（崖錐土）

表-6 $1 \mathrm{~m}^{3}$ 中のグラムイオン数

\begin{tabular}{|c|c|c|c|c|}
\hline 元素 番号 & (1) & (2) & (3) & (4) \\
\hline $\mathrm{Si}^{4+}$ & 30,385 & 12,554 & 11,979 & 11,769 \\
\hline $\mathrm{Ti}^{4+}$ & 189 & 158 & 119 & 126 \\
\hline $\mathrm{Al}^{3+}$ & 8,228 & 4,847 & 4,446 & 6,088 \\
\hline $\mathrm{Fe}^{3+}$ & 606 & 1,038 & 1,260 & 726 \\
\hline $\mathrm{Fe}^{2+}$ & 926 & 44 & 55 & 50 \\
\hline $\mathrm{Mn}^{2+}$ & 27 & 4 & 2 & 2 \\
\hline $\mathrm{Mg}^{2+}$ & 1,439 & 129 & 265 & 256 \\
\hline $\mathrm{Ca}^{2+}$ & 1,917 & 11 & 4 & 2 \\
\hline $\mathrm{Na}^{+}$ & 3,232 & 127 & 103 & 67 \\
\hline $\mathrm{K}^{+}$ & 1,448 & 669 & 657 & 531 \\
\hline $\mathrm{H}^{+}(-)$ & 733 & 3,247 & 3,439 & 5,397 \\
\hline $\mathrm{H}^{+}(+)$ & 3,239 & 10,922 & 11,040 & 12,610 \\
\hline $\mathrm{P}^{5+}$ & 58 & 18 & 62 & 22 \\
\hline
\end{tabular}

$\begin{array}{lll}\text { (1) : } 48031501 & \text { (2): } 48031503 & \text { (3) : } 48031504\end{array}$ (4)：48031505（崖錐土）

減少する順位吕 $\mathrm{Ca}^{2+}>\mathrm{Na}^{+}>\mathrm{Fe}^{2+}>\mathrm{Mg}^{2+}>\mathrm{Mn}^{2+}>\mathrm{P}^{5+}$ $>\mathrm{Si}^{4+}>\mathrm{K}^{+}>\mathrm{Al}^{3+}>\mathrm{Ti}^{4+}>\mathrm{Fe}^{3+}>\mathrm{H}^{+}(+)$となり, A.D.F. $=14.81$ のものでは $\mathrm{Ca}^{2+}>\mathrm{Na}^{+}>\mathrm{Mn}^{2+}>\mathrm{Fe}^{2+}>\mathrm{Mg}^{2+}$ $>\mathrm{Si}^{4+}>\mathrm{K}^{+}>\mathrm{Al}^{3+}>\mathrm{Ti}^{4+}>\mathrm{P}^{5+}>\mathrm{Fe}^{3+}>\mathrm{H}^{+}(+)$となる。 両者を比較すると $\mathrm{Mn}^{2+}, \mathrm{P}^{5+}$ を除いてよく一致してい ると云える。 $\mathrm{Mn}^{2+}$ については，この程度の風化岩にお いてその酸化物がしばしば斑点状に析出していることが あったり，脈状をなすことがあるのでその影響が現われ たのであろう。
表-7 岩石 $1 \mathrm{~m}^{3}$ 中のグラムイオン数減少率

\begin{tabular}{c|c|c|c}
\hline 計算式 & $\frac{(1)-(2)}{(1)} \times 100$ & $\frac{(1)-(3)}{(1)} \times 100$ & $\frac{(1)-(4)}{(1)} \times 100$ \\
\hline 元素 & $58.68(\%)$ & $60.58(\%)$ & $61.27(\%)$ \\
$\mathrm{Si}^{4+}$ & 16.40 & 37.57 & 33.33 \\
$\mathrm{Ti}^{4+}$ & 41.09 & 45.96 & 26.00 \\
$\mathrm{Al}^{3+}$ & 71.28 & $\oplus 107.92$ & $\oplus 19.80$ \\
$\mathrm{Fe}^{3+}$ & 95.25 & 88.66 & 94.60 \\
$\mathrm{Fe}^{2+}$ & 85.19 & 92.59 & 92.59 \\
$\mathrm{Mn}^{2+}$ & 91.04 & 81.58 & 82.21 \\
$\mathrm{Mg}^{2+}$ & 99.43 & 99.79 & 99.90 \\
$\mathrm{Ca}^{2+}$ & 96.07 & 96.81 & 97.93 \\
$\mathrm{Na}^{+}$ & 53.83 & 54.63 & 63.33 \\
$\mathrm{~K}^{+}$ & $\oplus 342.97$ & $\oplus 369.17$ & $\oplus 636.30$ \\
$\mathrm{H}^{+}(-)$ & $\oplus 237.20$ & $\oplus 240.85$ & $\oplus 289.32$ \\
$\mathrm{H}^{+}(+)$ & $\oplus 2.97$ & $\oplus 6.90$ & 62.07 \\
$\mathrm{P}^{5+}$ & 68.97 \\
\hline
\end{tabular}

$\oplus$ 印は增加率
(1) : 48031501
(4)：48031505（崖錐土）

$\mathrm{Al}_{2} \mathrm{O}_{3}$ が風化過程において不変とする意見もあるが， 実際には減少することが理解され, 前報9),10)や Hendrick et ${ }^{11)}$ の研究においてもそれが支持される。

$\mathrm{Ca}^{2+}, \mathrm{Na}^{+}$は大部分が斜長石成分であり，それが風化 によって著しく影響を受ける鉱物であることを示し，逆

表-8 黑雲母とその風化物の化学組成

\begin{tabular}{l|r|r|r|r|r}
\hline 成分 & \multicolumn{1}{c|}{ 番号 } & \multicolumn{1}{c|}{$(1)$} & \multicolumn{1}{c|}{$(2)$} & \multicolumn{1}{c|}{$(4)$} & \multicolumn{1}{c}{$(5)$} \\
\hline $\mathrm{SiO}_{2}$ & 35.66 & 35.36 & 33.93 & 38.28 & 37.36 \\
$\mathrm{TiO}_{2}$ & 4.08 & 3.88 & 5.23 & 2.21 & 2.29 \\
$\mathrm{Al}_{2} \mathrm{O}_{3}$ & 15.46 & 14.58 & 11.41 & 25.88 & 24.92 \\
$\mathrm{Fe}_{2} \mathrm{O}_{3}$ & 4.72 & 11.58 & 17.17 & 10.51 & 11.20 \\
$\mathrm{FeO}$ & 13.75 & 5.29 & 1.43 & 0.29 & 0.22 \\
$\mathrm{MnO}$ & 0.23 & 0.20 & 0.20 & 0.09 & 0.06 \\
$\mathrm{MgO}$ & 13.98 & 11.88 & 10.15 & 5.06 & 4.28 \\
$\mathrm{CaO}$ & 0.62 & 1.04 & 2.14 & 0.13 & 0.00 \\
$\mathrm{Na}{ }_{2} \mathrm{O}$ & 0.03 & 0.54 & 0.24 & 0.03 & 0.09 \\
$\mathrm{~K}_{2} \mathrm{O}$ & 6.50 & 4.09 & 2.41 & 1.51 & 1.69 \\
$\mathrm{H}_{2} \mathrm{O}(-)$ & 0.61 & 5.29 & 6.94 & 3.88 & 3.22 \\
$\mathrm{H}_{2} \mathrm{O}(+)$ & 3.37 & 5.65 & 8.93 & 12.34 & 13.84 \\
$\mathrm{P}_{2} \mathrm{O}_{5}$ & 0.34 & 0.30 & 0.29 & 0.30 & 0.49 \\
\hline Total & 99.35 & 99.68 & 100.47 & 100.51 & 99.66 \\
\hline 母 岩 の & 100.00 & 88.89 & 76.54 & 18.52 & 11.11 \\
\hline $\mathrm{A} . \mathrm{D} . \mathrm{F}$. & & & &
\end{tabular}

$\begin{array}{llll}(1): 48031501 & \text { (2): } 49051001 & \text { (3): } 49051002 \text { 。 }\end{array}$ (4) : $48031502 \quad$ (5) : 48031505 
に $\mathrm{K}^{+}$の減少順位が低いのは正長石が風化しにくい鉱物 であることを示す。この事は 表-8 における黑雲母の風 化過程における $\mathrm{K}^{+}$の挙動によっても支持される。

\section{7. 風化にともなう黒雲母の変化}

風化の指標として黒雲母のもつ意義は大きく，長沢 ${ }^{12)}$ はこれについて詳述している。

表-8 は黒雲母の風化過程における化学組成変化を示 したものである。残念ながら，著しく風化したもので は，附着物質の除去に問題があるので満足な実験結果が 得られなかったので省かざるをえなかった。しかし， $\mathrm{K}_{2} \mathrm{O}, \mathrm{FeO}$ の減少, $\mathrm{Al}_{2} \mathrm{O}_{3}, \mathrm{H}_{2} \mathrm{O}(+)$ の増加など, 後述 するその鉱物学的変化とよく調和している。

図-2 に拈いてその鉱物変化が示されている。さらに， その各々について検討する。

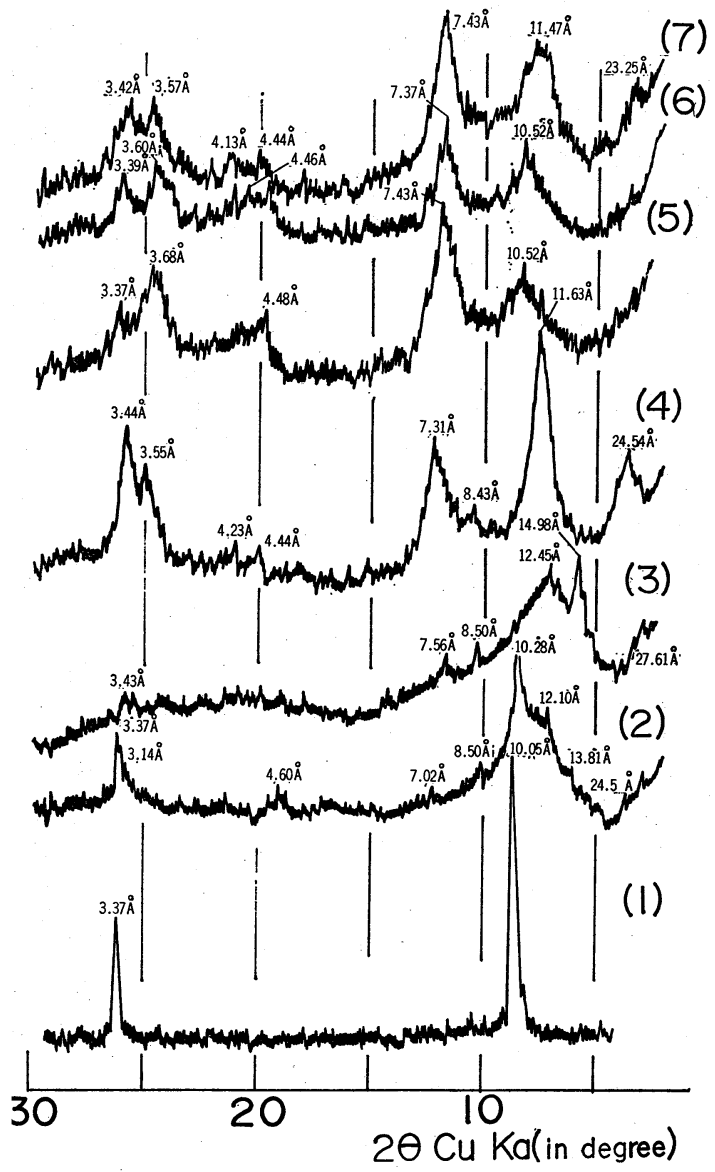

図-2 黒雲母とその風化物と $\mathrm{X}$ 線回折図（無処理） （番号は 表-2 の分析番号と同じ）

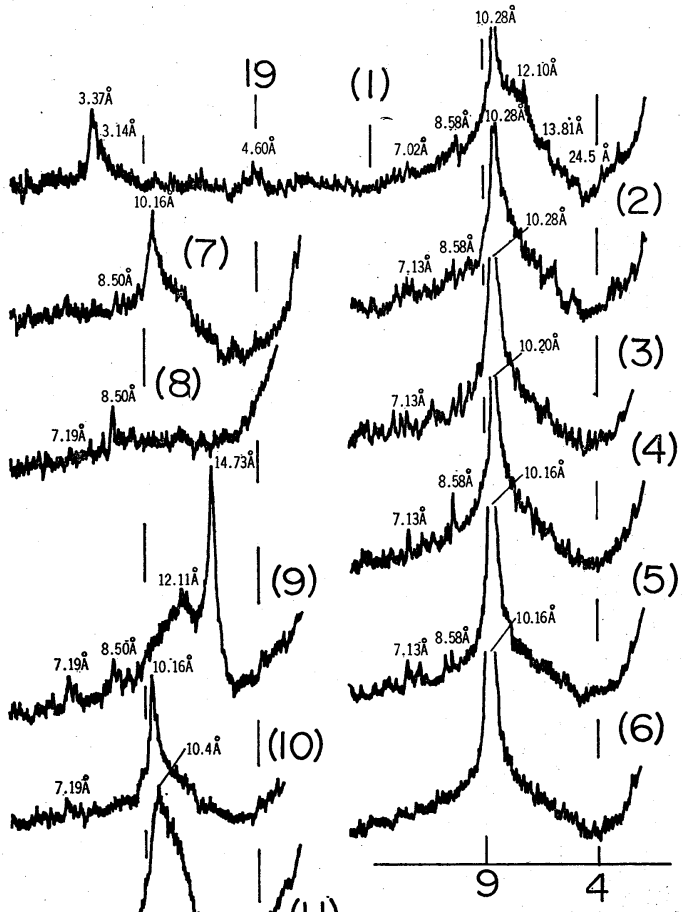

$2 \theta \mathrm{Cu} \mathrm{Ka(in} \mathrm{degree)}$

（1）無処理，（2） $200^{\circ} \mathrm{C}$ 加熱，（3） $300^{\circ} \mathrm{C}$ 加熱,

（4） $400^{\circ} \mathrm{C}$ 加熱，(5) $500^{\circ} \mathrm{C}$ 加熱，(6) $600^{\circ} \mathrm{C}$ 加熱,

(7) エチンン・グリコール処理，)8) $\mathrm{HCl}(1: 1)$ 処 理, (9) $\mathrm{MgCl}_{2}$ 処理, (10) $\mathrm{NH}_{4} \mathrm{NO}_{3}$ 処理, (11) $\mathrm{KCl}$ 処理

図-3 黒雲母風化物の X 線回折図（4905001）

図-3 は A.D.F.=88.89 の黒雲母に関するX線回折図 である。10.28 $\AA$ 附近の強い回折線は主として黒雲母型 格子に由来するものであろうが， $\mathrm{MgCl}_{2}, \mathrm{KCl}, \mathrm{NH}_{4} \mathrm{Cl}$ 各 溶液処理後の変化をみるとそれが容易にバーミキュライ トに移行しやすい不安定な状態の黒雲母に変化している と解釈される。12.10 附近のピークは, 加熱変化, $\mathrm{KCl}, \mathrm{NH}_{4} \mathrm{Cl}$ 各溶液処理の結果から，それが黒雲母とバ 一ミキュライトの混合層鉱物によるものと判断される。 この段階では僅かのカオリナイトが生成されているのが $7 \AA$ 附近のピークからうかがえる。

図-4 は A.D.F.=76.54 の黒雲母に関するX線回折図 である。各処理の結果から判断すると $14 \AA$ 附近にみら れるピークはその主体がバーミキュライトと判断される がその中に膨潤型格子をもっ鉱物が含まれている。恐ら く，それはモンモリロナイト型鉱物が混合層として含ま 


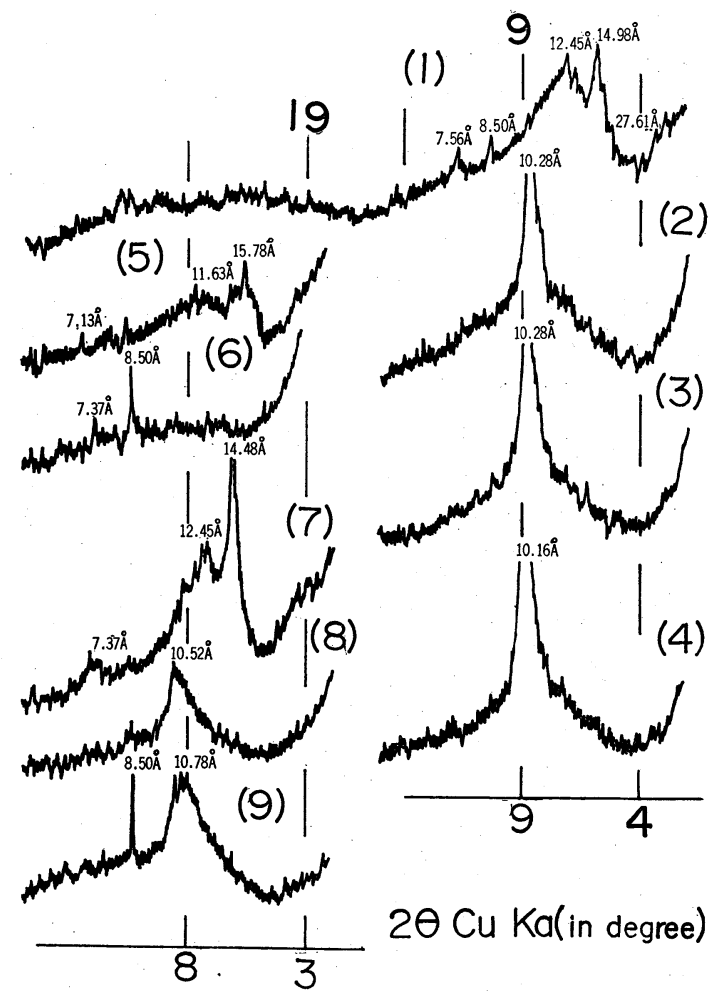

（1）無処理，（2） $300^{\circ} \mathrm{C}$ 加熱，（3） $500^{\circ} \mathrm{C}$ 加熱,

（4） $600^{\circ} \mathrm{C}$ 加熱，（5）エチレン・グリコール処理,

（6）塩酸処理, (7) $\mathrm{MgCl}_{2}$ 処理, (8) $\mathrm{NH}_{4} \mathrm{NO}_{3}$. 処

理, (9) $\mathrm{KCl}$ 処理

図-4 黒雲母風化物の $\mathrm{X}$ 線回折図（49051002）

れている可能性を示すかもしない。7 $\AA$ 附近のピークは カオリナイトによるものであろう。

図-5 は A.D.F.=18.52 の黑雲母に関するX線回折図 である。7.31 凡で示される強い回折線はカオリナイトに よるものである。また, $11.63 \AA$ の強い回折線は, 各処 理の結果から判断すると黒雲母と (Vermiculite-Chlorite intergrade) $)^{13)}$ の混合層鉱物であろうと判断される。

(Vermiculite-Chlorite intergrade) はバーミキュライト の層間陽イオンを交代して Al-hydroxy が入ったもの で，その層間陽イオンが非交換性の為に $\mathrm{K}^{+} や \mathrm{NH}_{4}+$ 処 理で縮まないものと解釈される。

図-6, 7 は A.D.F.=12.35 および 14.81 の黑雲母に 関するX線回折図である。10.52 $\AA$ 附近の幅広いピーク は各処理を通じて黒雲母に由来するものと解釈される。 また, $7.43 \AA, 7.37 \AA$ に見られるピークはカオリナイト に由来するものである。

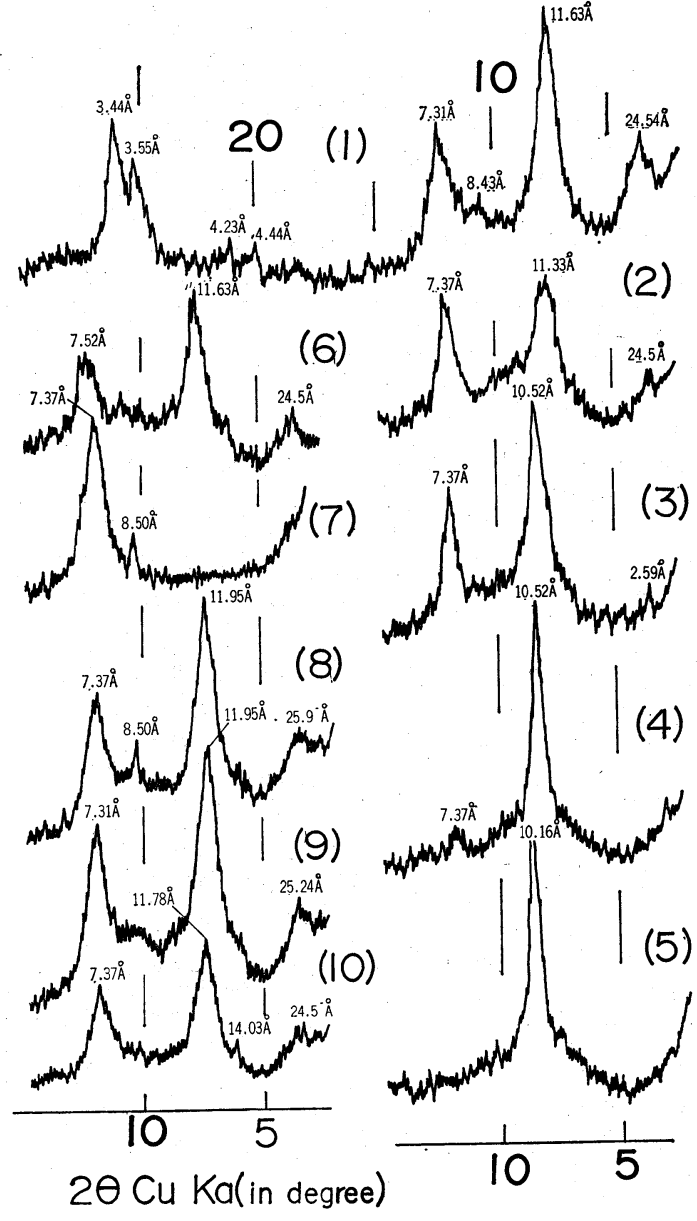

（1）無処理， (2) $300^{\circ} \mathrm{C}$ 加熱， (3) $400^{\circ} \mathrm{C}$ 加熱,

(4) $500^{\circ} \mathrm{C}$ 加熱, (5) $600^{\circ} \mathrm{C}$ 加熱, (6) エチンン・ グリコール処理, (7) $\mathrm{HCl}$ 処理, (8) $\mathrm{MgCl}_{2}$ 処理, 処理, (9) $\mathrm{NH}_{4} \mathrm{NO}_{3}$ 処理, (10) $\mathrm{KCl}$ 処理

図-5 黒雲母風化物の $\mathrm{X}$ 線回折図（48031502)

以上の結果を要約すると 表-9 の如くなる。これから 理解されるように，黒雲母の変化様式が式が風化過程に おける意味ある指標を与えていると云うことが出来るで あろう。

8.むすび

以上，大東花崗閃緑岩について，その風化過程におけ る化学的変化と黒雲母の鉱物学的変化について述べた。

これらの結果は, 応用地質学的諸事象の岩石学的検討 に対する方法論の確立に一つの暗示を与えるものと云え る。 


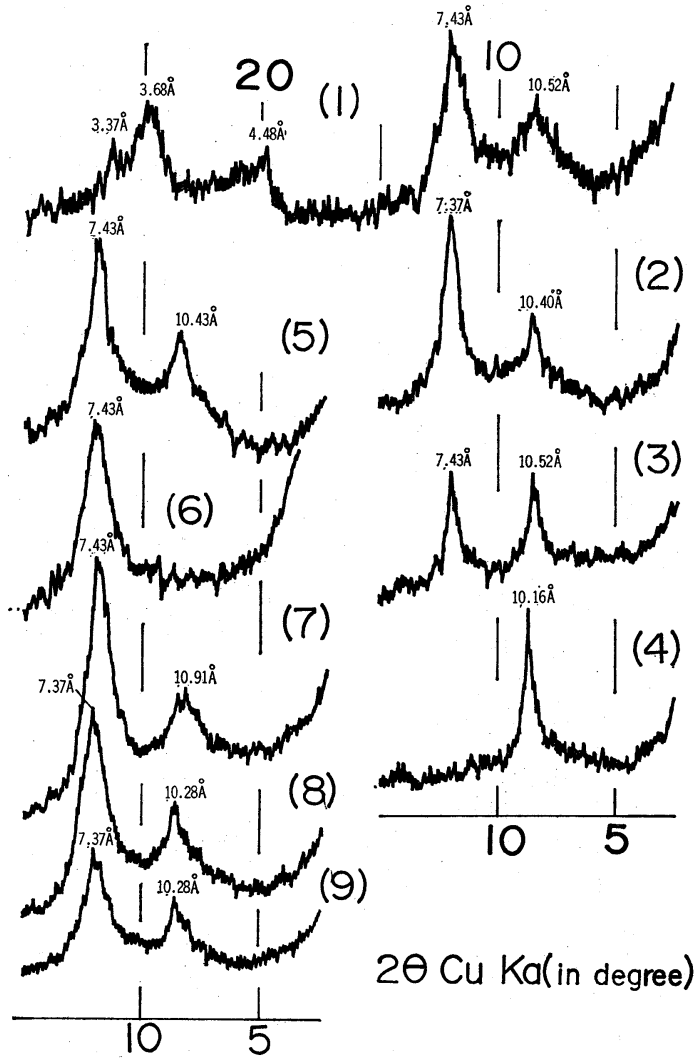

（1）無処理, （2） $300^{\circ} \mathrm{C}$ 加熱，（3） $500^{\circ} \mathrm{C}$ 加熱,

(4) $600^{\circ} \mathrm{C}$ 加熱, (5) エチンン・グリコール処理,

(6) $\mathrm{HCl}$ 処理, (7) $\mathrm{MgCl}_{2}$ 処理, (8) $\mathrm{NH}_{4} \mathrm{NO}_{3}$ 処

理, (9) $\mathrm{KCl}$ 処理

図-6 黒雲母風化物の $\mathrm{X}$ 線回折図（48031503）

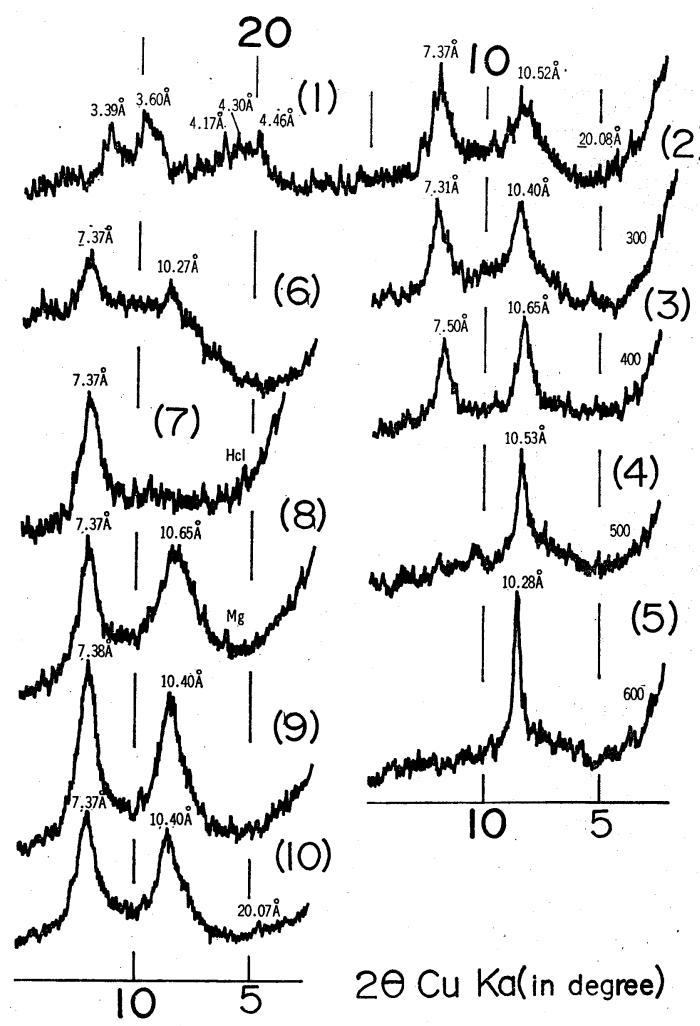

（1）無処理，（2） $300^{\circ} \mathrm{C}$ 加熱，（3） $400^{\circ} \mathrm{C}$ 加熱,

（4） $500^{\circ} \mathrm{C}$ 加熱，(5) $600^{\circ} \mathrm{C}$ 加熱，(6) エチンン・

グリコール処理, (7) $\mathrm{HCl}$ 処理, (8) $\mathrm{MgCl}_{2}$ 処理,

(9) $\mathrm{NH}_{4} \mathrm{NO}_{3}$ 処理, (10) $\mathrm{KCl}$ 処理

図-7 黒雲母風化物の $X$ 線回折図 (48031504)

表-9 黒雲母の風化過程にともなう鉱物变化

\begin{tabular}{c|l|c|c|c}
\hline A.D.F.=100 & 88.89 & 76.54 & 18.52 & $14.81-12.35$ \\
\hline \multirow{3}{*}{ Biotite } & Unstable Biotite & $\begin{array}{c}\text { Interstratified Vermiculite } \\
\text { Montmorillonite mineral }\end{array}$ & $\begin{array}{c}\text { Interstratified Biotite- } \\
\text { Vermiculite mineral }\end{array}$ & Kaolinite (minor content) \\
& Kaolinite (minor content) & $\begin{array}{c}\text { Interstratified Biotite- } \\
\text { (Vermiculite-Chorite } \\
\text { intergrade) mineral } \\
\text { Interstratified Biotite- } \\
\text { Vermiculite mineral }\end{array}$ & Kaolinite & Kaolinite \\
\hline
\end{tabular}

\section{参 考 文 献}

1）河野義礼，植田良夫 (1967): 本邦火成岩の $\mathrm{K}-\mathrm{Ar}$ dating (VI) -一花崗岩類, 総括一, 岩鉱, Vol. 59, No. 5, pp. $177 \sim 187$.

2) 三浦 清 $(1966,67)$ ：島根県加茂町付近の花崗 岩類とその崩壊について ( I ), (II), 岩鉱, Vol. 56 , No. 6 , pp. $256 \sim 283$, Vol. 57 , No. 1, pp.
$11 \sim 24$.

3）黑田和男，篞木時雨郎 (1973)：島根県大原郡下 の風化花崗岩地帯における山くずれの地質学的研 究, 防災科学技術総合研究報告, No. 30, pp. 7 22.

4）大八木規夫 (1968)：島根県加茂, 大東花崗岩類 地帯に打ける風化帯の構造と崩壞, 防災科学技術 総合研究報告, No. 14, pp. 113 127. 
5）安藤 武, 黒田和男, 柴藤喜平, 三浦 清 (1968): 島根県大原郡地方における崩壊とそれに関連する 花崗岩の風化機構について, 防災科学技術総合研 究報告, No. 14, pp. 31 75.

6) Chayes, F. (1957): A provision reclassification of granite: Geo. Mag., Vol. 94, pp. 58 68.

7）松井整司, 井上多津男 (1971): 三瓶火山の噴出 物と層序, 地球科学, Vol. 25, No. 4, pp. 147 163.

8）山陰第四紀グループ (1969)：山陰海岸地域の第 四系, 日本の第四系（地図研専報 15), pp. 356 376.

9）三浦 清 (1973)：深成岩の風化に関する研究 (第 1 報)一一新第三紀末の赤色風化作用による江 津深成岩体の風化, 応用地質, Vol. 14, No. 3, pp. $1 \sim 16$.

10）三浦 清，樋口和之（1974）：深成岩の風化に関 する研究 (第 2 報)一一鳥取県日野閃緑岩体の赤色 風化，応用地質，Vol. 15, No. 1, pp. 23〜34.

11) HENDRICKS, D. M., and WhitTing, L. D. (1968): Andesite weathering II. Geochemical changes from andesite to saprolite: Jour. Soil Sci., Vol. 19, pp. 147 153.

12）長沢敬之助 (1972)：風化過程におけるウンモの 変質, 鉱物学雑誌, Vol. 10, No. 6, pp. 528 539 .

13) Birkeland, P. W. (1974): Pedology, Weathering, and Geomorphological research: (Oxford Univ. Press).

（昭和 50 年 5 月 14 日受理） 